\title{
16S rRNA gene-based molecular analysis of mat-forming and accompanying bacteriacovering organically-enrichedmarinesediments underlying a salmon farm in Southern Chile (Calbuco Island)
}

\section{Análisis molecular basado en secuencias del gen ARNr 16s en bacterias formadoras de tapete y bacterias acompañantes en sedimentos marinos enriquecidos orgánicamente por una instalación de cultivo de salmones en el sur de Chile (isla Calbuco)}

\author{
Carlos Aranda ${ }^{1 *}$, Javier Paredes ${ }^{1}$, Cristian Valenzuela ${ }^{1},{\text { Phyllis } \text { Lam }^{2} \text { \& Laure Guillou }}^{3}$ \\ ${ }^{1}$ Centro i-mar, Universidad de Los Lagos, Camino a Chinquihue Km. 6, Casilla 557, Puerto Montt, Chile. \\ ${ }^{2}$ Max Planck Institute for Marine Microbiology, Celsiusstrasse 1, D-28359 Bremen, Germany. \\ ${ }^{3}$ Station Biologique de Roscoff, UMR 7144, CNRS and Université Pierre \& Marie Curie, BP74, 29682 Roscoff Cedex, \\ France. \\ *E-mail: caranda@ulagos.cl
}

\begin{abstract}
The mat forming bacteria covering organic matter-enriched and anoxic marine sediments underlying a salmon farm in Southern Chile, were examined using 16S rRNA gene phylogenies. This mat was absent in the sea bed outside the direct influence of the farm (360 m outside fish cages). Based on nearly complete $16 \mathrm{~S}$ rRNA gene sequences $(\sim 1500 \mathrm{bp})$, matforming filamentous cells were settled as the sulphur-oxidizing and putatively dissimilative nitrate-reducing Beggiatoa spp., being closely related (up to $97 \%$ sequence identity) to Beggiatoa spp. identified in eutrophic shallow sediments in northern Europe (Danish Limfjorden and German Dangast inlets). Their phylogenetic affiliation was consistent with their morphology as vacuolated and sulphur-containing cells arranged on tandem along trichomes (18 to $28 \mu \mathrm{m}$ diameter). Additionally, deltaproteobacterial sulphate reducers, Sulfurospirillum, Sulfurovum and Fusibacter were detected according to partial 16S rRNA gene sequences ( $\sim 500 \mathrm{bp})$. Their concurrence with Beggiatoa suggested an intense and complex sulphur cycle within the surface of these aquaculture-affected sediments, which may have important implications for the necessity of more efficient benthic-bioremediation of finfish aquaculture in Chile and worldwide.
\end{abstract}

KeYwoRDs: 16S rRNA genes, Beggiatoa mat, salmon farming sediments, sulphur cycle.

\section{RESUMEN}

Las bacterias formadoras de tapete sobre sedimentos anóxicos enriquecidos orgánicamente por residuos de una instalación de cultivo intensivo de salmones en el sur de Chile fueron examinadas a partir de sus secuencias del gen ARNr 16S. Este tapete está ausente en el lecho marino que está fuera de la influencia directa de la instalación de cultivo (360 m alejado de las balsas jaula). Según el análisis de secuencias casi completas de este gen ( 1500 bp), las células filamentosas formadoras de tapete fueron identificadas como sulfuro-oxidantes Beggiatoa spp., del tipo vacuolado y putativamente capaces de reducir desasimilatoriamente nitrato en amonio, siendo estrechamente relacionadas (hasta 97\% de homología) con Beggiaota spp. identificadas en sedimentos de baja profundidad en mares interiores eutroficados de Dinamarca (Limfjorden) y el norte de Alemania (Dangast). Esta afiliación filogenética fue consistente con la morfología caracterizadora, es decir, presencia de células discoidales con vacuolas y gránulos de azufre, dispuestas a lo largo de un tren o tricoma de 18 a $28 \mu \mathrm{m}$ de diámetro. Adicionalmente, deltaproteobacterias reductoras de sulfato, Sulfurospirillum, Sulfurovum y Fusibacter fueron también detectados de acuerdo a sus secuencias parciales del gen ARNr 16S ( 500 bp). La concurrencia de estas células con los filamentos de Beggiatoa sugieren el funcionamiento de un ciclo de azufre intenso y complejo ocurriendo en la superficie de estos sedimentos afectados por el cultivo de salmones, ciclo que puede aportar importantes consideraciones biológicas a la necesidad de un biocontrol y/o biorrermediaición del impacto bentónico por la acuicultura de peces marinos en Chile y el mundo.

Palabras clave: Ciclo de azufre, genes16S rARN, salmonicultura, sedimentos, tapete de Beggiatoa. 


\section{INTRODUCTION}

The inland seas of Southern Chile (south-west coasts of South America) provide an intricate system of protected fjords and shallow channels with good conditions for aquaculture. Mild temperatures and abundant regular freshwater inputs represent highly competitive advantages for salmon and trout farming, making Chile one of the top producers of these species in the world (Buschmann et al. 2008).

One of the key environmental concerns of this large-scale industry is the accumulation of organic wastes (fish faecalmatter and uneaten food) on the sea-bed beneath fish-cages. These accumulations increase anaerobic microbial metabolisms in sediments and raise emissions of environmentally undesirable chemicals, like $\mathrm{H}_{2} \mathrm{~S}$ and methane into the water column. The sulphide in the interstitial layer could be oxidized by superficial microbial white mats dominated by the big filamentous bacteria classified as Beggiatoa sp. (Schulz \& Jørgensen 2001; Jørgensen et al. 2005), which have been frequently used as indicators for environment pollution underneath aquaculture operations in the world (Buschmann et al. 2008; Bissett et al. 2006; Brooks et al. 2003).

Beggiatoa are morphologically and physiologically heterogenic (Schulz \& Jørgensen 2001). Some marine species contain nitrate-accumulating vacuoles and are able to couple sulphide-oxidation with dissimilative nitrate-reduction to ammonium (DNRA) (Jørgensen et al. 2005). At present, most detailed studies of Beggiatoa-mats and interacting bacteria have been performed in sulphide-rich sediments beneath extensive upwelling marine regions (Schulz et al. 1996), deep-sea hydrothermal vents (Nelson et al. 1989), sulphiderich cold seeps (Lloyd et al. 2006, 2010; Mills et al. 2004; McHatton et al. 1996) and shallow marine sediments with natural or anthropogenic organic enrichment (Sayama et al. 2005; Kojima \& Fukui 2003; Mussmann et al. 2003). However, studies of such communities and geochemical implications in marine sediments organically enriched by aquaculture operations are scarce (e.g. Bissett et al. 2006; Asami et al. 2005; Christensen et al. 2000) and even completely absent for aquaculture-exposed Chilean environments.

In the present study, mat forming cells covering the surface of sediments underlying fish-farming cages in Southern Chile, were examined using a culture-independent approach based on their 16S rRNA gene phylogenies.

\section{MATERIALS AND METHODS}

Study Site

The study site was a salmon farm located in Calbuco Island, Southern Chile ( $\left.41^{\circ} 48^{\prime} \mathrm{S}, 73^{\circ} 11^{\prime} \mathrm{W}\right)$ (Fig. 1). Studies were performed before the recent sanitary farm reset due to the infectious salmon anemia (ISA) outbreak that affected most of industry in the Region (years 2008 and 2009). Farming of salmon and restocking with new smolts had been performed progressively in the tandem-arranged cages of the farm, allowing a continuous fish production of 2500 to 3000 tons per year until 2008. Preliminary submarine imaging (June 2006) revealed an almost complete coverage of seabed underneath the salmon farm by a white microbial mat, putatively dominated by Beggiatoa sp., which was absent outside the fish cages of radii ranging between 10 to $60 \mathrm{~m}$ according to the dominant local marine current. A reference site with no visible microbial mats was also chosen for preliminary analyses, this site was at $360 \mathrm{~m}$ away from the fish cage at similar depth (Fig. 1).

SAmpling and Preliminary Analyses.

Sediment samples were collected underneath fish-cage nets by scuba divers in two independent sampling campaigns (August 2006 and June 2007; depth at low tide: $35 \mathrm{~m}$ ). The samples were always transported in ice and in the dark, to be processed in less than 2 hours. For preliminary sediment analyses for both the study site and reference site, sediment cores of $100 \times 26 \mathrm{~mm}$ diameter were collected without destroying the bacterial mat (absent in the reference site). Redox potential (Eh) and $\mathrm{pH}$ were measured at $2 \mathrm{~cm}$ depth (pH meter 330i, WTW, Weilheim, Germany). Undisturbed cores (6 underneath the farm and 3 in the reference site) were sliced in $1-\mathrm{cm}$ intervals ( 0 to $8 \mathrm{~cm}$ depth), frozen at -80 ${ }^{\circ} \mathrm{C}$, lyophilized and later combusted in a bench top muffle furnace $\left(800^{\circ} \mathrm{C}, 6 \mathrm{~h}\right)$ to determine organic matter contents. Three additional cores of sediments underlying the farm were similarly sliced to be examined under inverted light microscopy (Eclipse TS100, Nikon Inc, USA) with CCTV camera coupled to video recording.

For microbial phylogenetic analyses, nine undisturbed sediment cores underlying the farm (study site, Fig 1) with 9 to $14 \mathrm{~mL}$ of overlying seawater were selected. The upper layer of seawater was gently extracted and replaced with sterile oxygenated seawater (SOSW, made by combination of degassed and air-saturated $0.2 \mu \mathrm{m}$ filter-sterilized seawater to achieve 8.1 to $9.2 \mathrm{mg} \mathrm{O}_{2} / \mathrm{L}$ ). These samples were then closed and incubated overnight at $10{ }^{\circ} \mathrm{C}$ to allow oxygen consumption and gliding of mat forming cells into the overlaying-seawater. After incubation, gliding filaments were gently aspirated with a sterile disposable Pasteur pipette (Kojima \& Fukui 2003; Ahmad et al. 1999), and then transferred to $100 \mathrm{~mL}$ sterile polypropylene flask filled with SOSW. Filaments were gently dispersed by pipetting up and down and then incubated for 3 hours at $4{ }^{\circ} \mathrm{C}$. During these incubations, mat-forming filamentous cells decanted and exhibited a self-aggregating behaviour to form a dense mass of motile filaments at the bottom of containers. Dispersion in 
fresh SOSW followed by self-aggregation of filaments was repeated twice in order to reduce carry-overs of sediment particles and bacteria unattached to the Beggiatoa-like cells. Integrity and purity of filamentous cells were checked by microscopy.

PCR Amplification, Cloning and Sequencing.

Twenty milligrams of self-aggregated filaments collected in August 2006 (in the study site) were rinsed three times in 500 $\mathrm{mL}$ of sterile phosphate buffered saline $(20 \mathrm{mM}$ phosphate buffer, $130 \mathrm{mM} \mathrm{NaCl}, \mathrm{pH}$ 7.2), followed by centrifugation at $10000 \mathrm{x} g$ for $5 \mathrm{~min}$. Final pellet was resuspended in 200 $\mu \mathrm{L}$ of sterile water and lysed by two freezing (liquid $\mathrm{N}_{2}$ ) and thawing $\left(42{ }^{\circ} \mathrm{C}\right)$ cycles followed by heating at $95{ }^{\circ} \mathrm{C}$ for 20 min. After centrifugation at $10000 \mathrm{x} g$ for $10 \mathrm{~min}$, an aliquot of cell extract was used as a template for partial 16S rRNA gene amplification using Recombinant Taq DNA Polymerase (Invitrogen, USA) and universal primers for the domain Bacteria: 8fpl (5'-AGAGTTTGATCCTGGCTCAG-3') and 534R (5'-ATTACCGCGGCTGCTGG-3') (Kalanetra et al. 2004). Thermal cycling was carried out with following protocol: $94^{\circ} \mathrm{C}$ for $5 \mathrm{~min}, 30$ cycles of $94^{\circ} \mathrm{C}$ for $1 \mathrm{~min}, 60^{\circ} \mathrm{C}$ for $1 \mathrm{~min}, 72^{\circ} \mathrm{C}$ for $1 \mathrm{~min}$ and a final step at extension at 72 ${ }^{\circ} \mathrm{C}$ for $15 \mathrm{~min}$. The PCR product of $\sim 500 \mathrm{bp}$ was purified with PureLink PCR-purification kit (Invitrogen). Genomic DNA of mat-forming cells (self-aggregating filaments) collected in June 2007 in the study site was directly purified by UltraClean Soil DNA kit (MO BIO Laboratories, CA, USA) and used as templates for 16S rRNA gene amplification with universal primers for the domain Bacteria: GM3 forward (5'-AGAGTTTGATCMTGGC-3') and GM4 reverse (5'TACCTTGTTACGACTT-3') (Muyzer et al. 1995). The thermal cycling protocol consisted in $94{ }^{\circ} \mathrm{C}$ for $5 \mathrm{~min}, 25$ cycles of $94{ }^{\circ} \mathrm{C}$ for $1 \mathrm{~min}, 48{ }^{\circ} \mathrm{C}$ for $1.5 \mathrm{~min}, 72{ }^{\circ} \mathrm{C}$ for 2 min and a final step of extension at $72{ }^{\circ} \mathrm{C}$ for $15 \mathrm{~min}$. The PCR product was purified using QIAquick purification kit (Qiagen).

The purified PCR products from both samples were used for clone library constructions, using Topo TA cloning system (Invitrogen) following the instructions provided by the manufacturer. Ninety five clones with the proper insert size of the 2006 sample $(\sim 500 \mathrm{pb})$ were selected for sequencing with a Big Dye v.3 kit (Applied Biosystems) and analysed in an ABI PRISMs model 3100 automated sequencer (Applied Biosystems). Reactions were performed with the M13R primer to fully sequence the partial length $16 \mathrm{~S}$ rRNA PCR product. In the case of the 2007 sample, 93 clones with a proper size insertion $(\sim 1500 \mathrm{pb})$ were selected and sequenced with the M13R and T7 for a nearly full-length $16 \mathrm{~S}$ rRNA gene.

Phylogenetic Analyses.

Assembling and aligning of $16 \mathrm{~S}$ rDNA sequence data were performed with the program MEGA4 (Tamura et al. 2007).
Chimeric 16S rDNA sequences were checked with the programs Chimera Check version 2.7 (Cole et al. 2003) and Bellerophon (Huber et al. 2004). Retrieving of GenBank homologues was performed in October 2009 by Megablast (Benson et al. 2000). Sequence affiliations were supported by a Naïve Bayesian rRNA classifier (Wang et al. 2007) and phylogenetic analyses by PAUP 4.0b10 (Sinauer Associates, MA, USA) with maximum parsimony (MP) and neighbourjoining (NJ) criteria (tree reliabilities supported by 1000 bootstrap replicates calculated for each criteria).

Sequences Accession Numbers.

Sequences obtained from this study have been deposited in GenBank under accession numbers FJ875151-FJ875194 for partial 16S rRNA gene sequences and FJ875195FJ875199 for nearly complete Beggiatoa-like16S rRNA gene sequences. Sequences with one or more resamplings at $100 \%$ sequence identity were deposited just once.

\section{RESULTS}

SAmpling and Preliminary Analyses.

Undisturbed cores of the study site (collected in both sampling campaigns) showed a dense Beggiatoa-like mat ( 0.2 to 0.5 $\mathrm{cm}$ thick) covering a 2 to $3 \mathrm{~cm}$ layer of silty mud gradually mixed with mineral sand and ground shells sediments. All these cores had a strong hydrogen sulphide odour. Light microscopic analyses of sediment slices showed that most of the mat-forming filamentous cells inhabited only the upper layer of sediments $(0-1 \mathrm{~cm})$. Organic matter content inside the sediments decreased with depth of the slice analysed, from $5.1 \pm 1.3 \%$ dry weight (mean $\pm \mathrm{SD}, \mathrm{n}=6)$ at $0-1 \mathrm{~cm}$ sediment depth to $1.5 \pm 0.3 \%$ at 6-7 $\mathrm{cm}$, with no differences between the first and the second sampling campaigns. In the reference site at $360 \mathrm{~m}$ outside farm (Fig. 1) the Beggiatoa mat was absent, and the respective organic matter contents (in 2007) were $2.3 \pm 0.7 \%$ and $1.1 \pm 0.5 \%$ dry weight (n $=3$ ). Additionally, submerged electrodes at $2 \mathrm{~cm}$ sediment depth underneath the farm revealed complete depletion of oxygen, reaching redox potential values (Eh) even lower than $-350 \mathrm{mV}$ with $\mathrm{pH}$ ranging between 5.9 and 6.3 , while the reference site reached $\mathrm{Eh}-115 \mathrm{mV}$ and $\mathrm{pH}$ 6.5. These measurements indicated that sediments sampled underneath the fish farm were organically enriched and consequently turned hypoxic due to intense bacterial activity.

Phylogenetic Analyses by Partial 16S Sequences. A clone library of fifty-three partial $16 \mathrm{~S}$ rDNA sequences $(\sim 500 \mathrm{bp})$ resulted from the 2006 mat-forming cells sample (Fig. 2). This library was composed by undefined Bacteria (13 clones), phylum Firmicutes (14 clones) and phylum Proteobacteria (26 clones), all grouped into 18 operating taxonomic units (OTUs) at $95 \%$ of sequence identity. The 
undefined bacteria were all grouped into the most abundant OTU of this library (Clone Ca1-A05, plus 7 identical clones and other 5 sequences), which have some undefined eukaryotic plastids or prasinophycean chloroplasts as close relatives from the GenBank database.

The clones of phylum Firmicutes were grouped in 5 OTUs. The major one (clone Cal-A8 plus 4 clones) had the bacterium Fusibacter paucivorans (Ravot et al. 1999) between the nearest cultured relatives. A second Firmicutes OTU includes three clones clustered with Geobacillus sp. This heterotrophic and thermophilic Gram-positive bacteria has been isolated from various geographically and ecologically diverse low-temperature settings (Marchant $e t$ al. 2002), where their abilities to form viable spores were likely required. The remaining three Firmicutes OTUs were assigned to the order Clostridiales by the Naïve Bayesian rRNA classifier and the closest relatives found in the GenBank database were some uncultured Firmicutes sequences retrieved from black-band diseased coral tissue and putative sulphide-oxidizing microbial mat in Antarctic marine sediments.

The phylum Proteobacteria was represented by the majority of clones in this library, all belonging to Deltaproteobacteria, Gammaproteobacteria and Epsilonproteobacteria classes. The class Deltaproteobacteria was represented by five potentially sulphate-reducing bacteria (SRB) OTUs. Three of these OTUs were assigned to the Desulfobulbaceae family, being the first one (clones Ca1-E02 and Ca1F03) clustered with an uncultured bacterium retrieved from sulphide-oxidizing microbial mat of Antarctic marine sediments and the uncultured Dasulfocapsa sp. retrieved also from Antarctic marine sediments (GenBank accessions: FJ223325 and AY177798). The second Desulfobulbaceae OTU (clone Ca1-H12) clustered with one uncultured bacterium (GenBank accession: EU362301) and the sulphate-reducing bacterium strain SFA3 (GenBank accession: AJ866936), both retrieved from different organically-enriched tidal flat sediments. The last Desulfobulbaceae OTU (clones CA1-F02 and Ca1-F04) belong to the genus Desulforhopalus and clustered with an uncultured bacterium isolated from a river methane seep and a cultured psychrophilic SRB (GenBank accessions: FJ264675 and AF099059). The additional two Deltaproteobacteria OTUs were two Desulfobacteraceae sequences (Ca1-C31 and Ca1-D11) clustered with an uncultured marine blooming bacterium from sulphidic African shelf water (Lavik et al. 2009) and an uncultured bacterium from temperate estuarine mud (GenBank accessions: FM246545 and AY216443). Additionally, the class Gammaproteobacteria was represented by 4 clones, with two (Ca1-D09 and Ca1-A07), differing only in one out of 523 nucleotides analysed and falling into the order Thiotrichales with the uncultured Beggiatoa sp. clone Limfjorden L22 (Mussmann et al. 2003) as the nearest relative (see next section for a more complete analysis). The remaining two Gammaproteobacteria clones were closely related to Pantoea sp. (family Enterobacteriaceae) and Psychromonas sp. (family Psychromonadaceae), respectively. Finally, Epsilonproteobacteria were the most frequently class obtained in this library, being

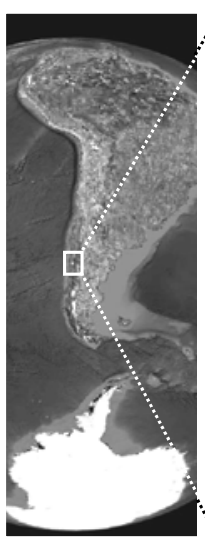

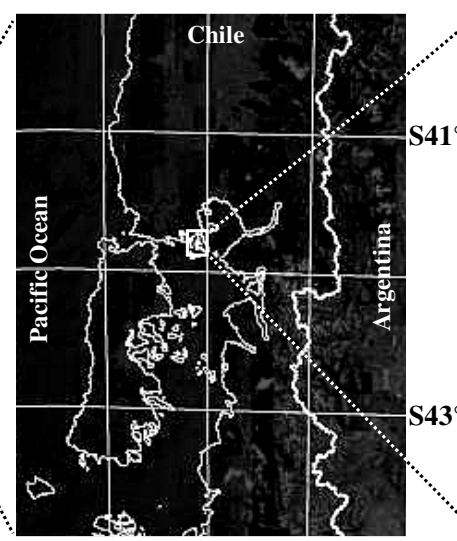

W74 $^{\circ}$

W72
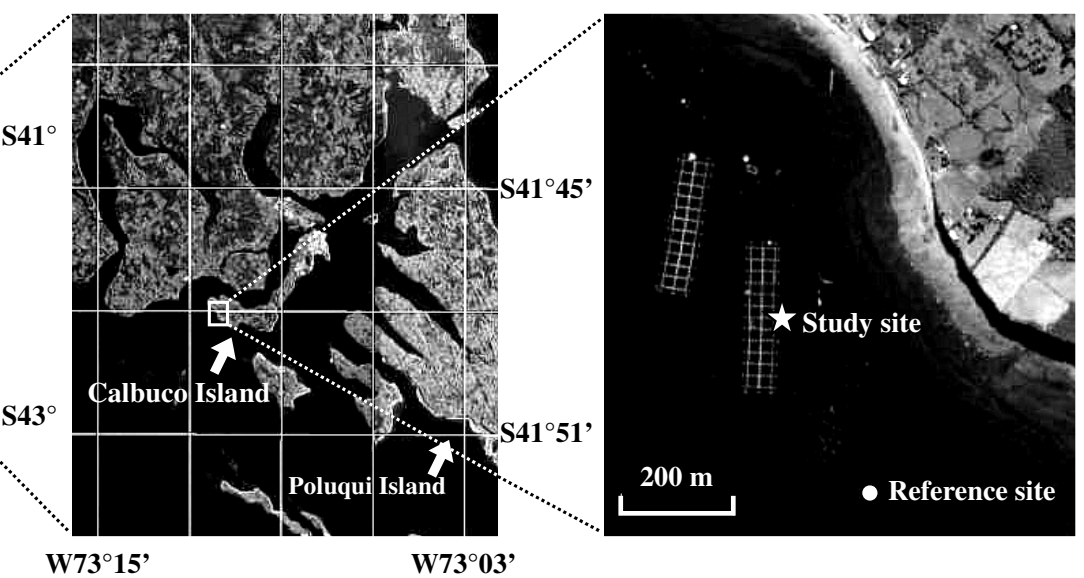

FigURE 1. Maps of study area showing relative locations of the study site, the reference site and the tandem-arranged cages for salmon farm in Calbuco Island (taken from Google Earth). Water depth below study and reference sites varies between 35 and $45 \mathrm{~m}$, depending on the tidal cycle.

Figura 1. Mapas del área de estudio que muestran la ubicación relativa del sitio de estudio, el sitio de referencia y los trenes de balsas jaula de cultivo de salmones en la Isla Calbuco (obtenidos desde Google Earth). La profundidad en el sitio de estudio y en el de referencia varía entre 35 y $45 \mathrm{~m}$ dependiendo del ciclo de marea. 


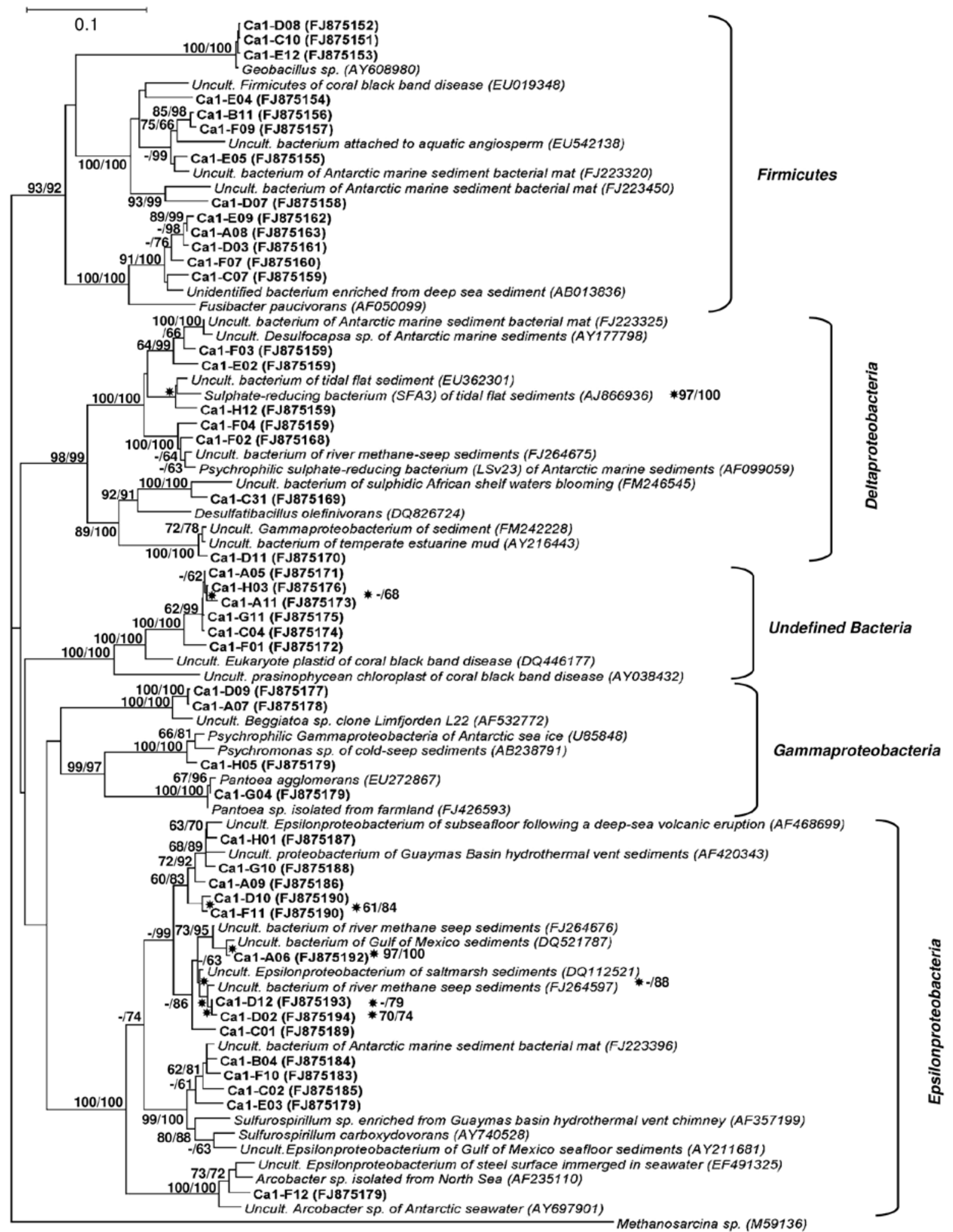

FIGURE 2. Tree indicating the phylogenetic relationships inferred from partial 16S rRNA gene sequences (E. coli position 8 to 534$)$ of clones retrieved from the first mat-forming cells sample (boldface type) and selected nearest relatives from GenBank database. Bootstrap support values for two phylogenetic criteria (MP/NJ) are showed adjacent to the correspondent node. Dash (-) indicates bootstrap support less than $60 \%$. GenBank accession numbers are shown in parenthesis. Resamplings at 100\% identity (not included in the tree) were: 7 for Ca1-05, 1 for Ca1-D07 and 1 for Ca1-F10. The tree was rooted with Methanosarcina sp. (M59136). 
FIGURA 2. Árbol indicando las relaciones filogenéticas inferidas a partir de las secuencias parciales del gen 16S rARN (posiciones para E. coli desde 8 a 534) de clones obtenidos de la primera muestra de células formadoras de tapete (negritas) y secuencias de referencia seleccionadas desde la base de datos GenBank. Los valores de boostrap para los criterios de máxima parsimonia y neighbour-joining son mostrados a un costado del nodo correspondiente (MP/NJ). La ausencia de un valor indica una confiabilidad de nodo inferior al $60 \%$. Los números de acceso para la base de datos GenBank están mostrados entre paréntesis. Los remuestreos con 100\% de identidad (no incluidos en el árbol) fueron: 7 para Ca1-05, 1 para Ca1-D07 y 1 para Ca1-F10. Se usó Methanosarcina sp. (M59136) como raíz del árbol.

grouped into 4 OTUs at $95 \%$ sequences identity. Two of these OTUs were assigned to the genus Sulfurovum (clones $\mathrm{Ca} 1-\mathrm{H} 01, \mathrm{Ca} 1-\mathrm{A} 06$ and their relatives) with uncultured bacteria samples from hydrothermal vent (Teske et al. 2002) and river methane seep sediments as the closest relatives (GenBank accessions: AF420343 and FJ264676). The third OTU (clone Ca1-F10, other identical, plus other 3 sequences) belong to the genus
Sulfurospirillum, with an uncultured bacterium clone retrieved from putative sulphide-oxidizing microbial mat in Antarctic marine sediments and Sulfurospirillum sp. enriched from hydrothermal vent chimney as the nearest uncultured and cultured relatives (GenBank accessions: FJ223396 and AF357199). The last Epsilonproteobacteria OTU contained only one clone (Ca1-F12) and was closely related to Arcobacter sp. (Fig. 2).

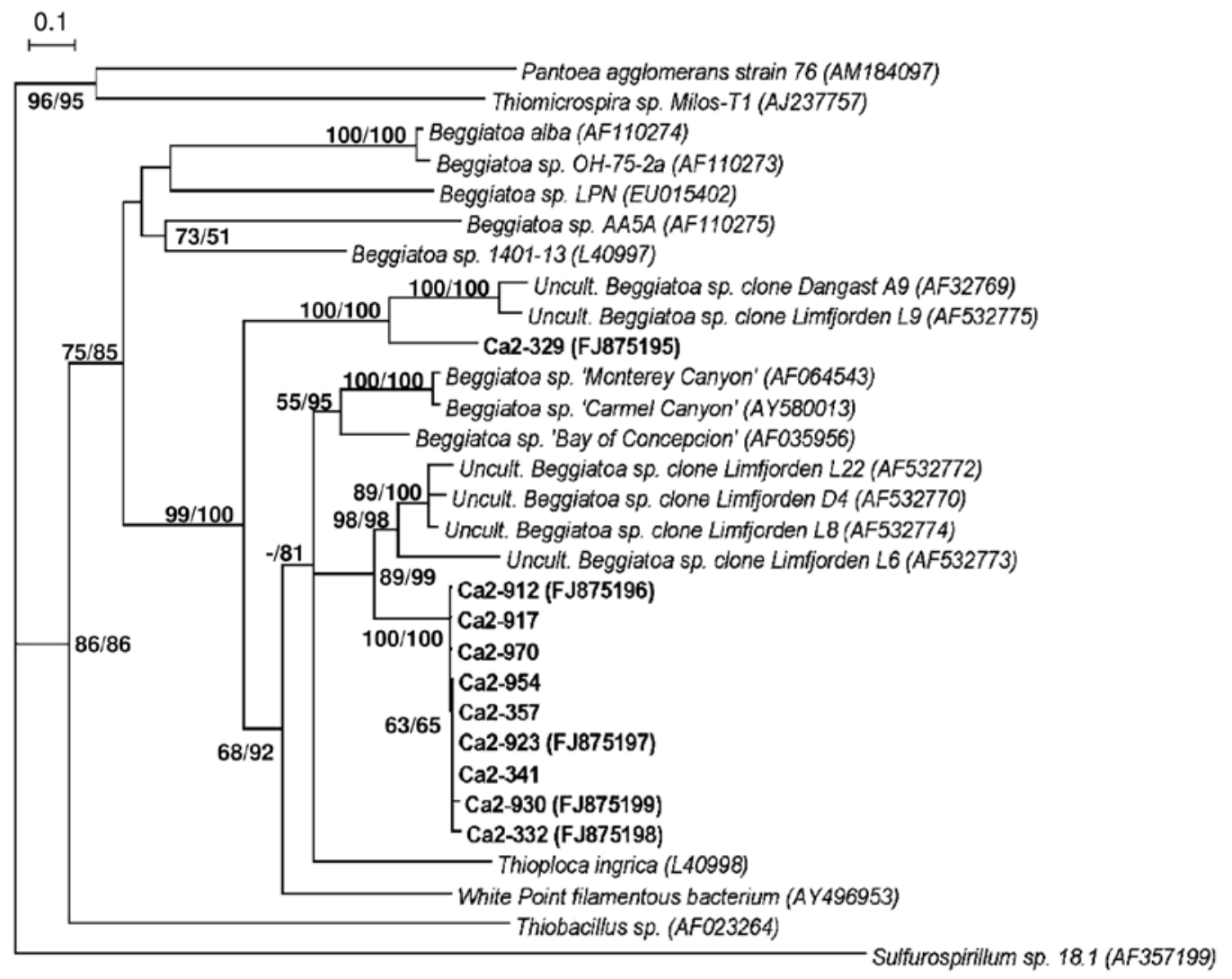

FIGURE 3. Tree indicating phylogenetic relationships inferred from near complete 16S rRNA gene sequences (E. coli position 29 to 1490$)$ of Beggiatoa sp. clones from the second mat-forming cells sample (boldface type), closest references from GenBank database, other Thiotrichales and some outlier Gammaproteobacteria. Bootstrap support values for two phylogenetic criteria (MP/NJ) are showed adjacent to the correspondent node. Dash (-) indicates bootstrap support less than 50\%. GenBank accession numbers are shown in parenthesis. Clones without GenBank accessions are the resamplings at 100\% sequence identity for Ca2-912 and Ca2-923. The tree was rooted with Sulfurospirillum sp. (AF357199).

FIGURA 3. Árbol indicando las relaciones filogenéticas inferidas a partir de las secuencias casi completas del gen 16S rARN (posiciones para E. coli desde 29 a 1490) de clones de Beggiatoa spp. obtenidos de la segunda muestra de células formadoras de tapete (negritas), secuencias de referencia obtenidas de las base de datos GenBank, otros Thiotrichales y algunas Gammaproteobacteria como referencias externas. Los valores de boostrap para los criterios de máxima parsimonia y neighbour-joining (MP/NJ) son mostrados a un costado del nodo correspondiente. La ausencia de un valor de boostrap indica confiabilidad de nodo inferior al 50\%. Los números de acceso para la base de datos GenBank son mostrados entre paréntesis. Las anotaciones sin este número son remuestreos con 100\% de identidad para los clones Ca1-912 y Ca1-923. Se usó Sulfurospirrillum sp. (AF357199) como raíz del árbol. 
Phylogenetic analyses of Beggiatoa by near-complete 16S SEQUENCES

In the second sample for the same study site (year 2007), only 10 almost full-length Beggiatoa-like 16S rRNA gene sequences were obtained. The phylogenetic analysis (Fig. 3) shows that all of them formed a well-defined clade with the Thioploca/Beggiatoa cluster of vacuolated sulphur-oxidizing filamentous bacteria (99 and 100\% for MP and NJ bootstraps) (89-97\% sequence similarities) (Jørgensen et al. 2005). They were relatively distant to the freshwater Beggiatoa alba and Beggiatoa spp. strains OH-75-2a, LPN, AA5A and 1401-13 (85-89\% sequence similarities). The majority of the near-complete $16 \mathrm{~S}$ rRNA gene sequences of Beggiatoa sp. have a fragment sharing $100 \%$ identity with the partial $16 \mathrm{~S}$ rRNA gene sequences retrieved in the first library (performed almost one year before). For instance, the partial sequence ( $\sim 50 \mathrm{bp})$ of clone Ca1-A07 was 100\% identical to the corresponding positions in the near-complete sequences of Ca2-912, Ca2-917 and Ca2-970; and the same applies for the partial sequence of clone Ca1-D09 to the nearly full sequences of Ca-332 Ca-341, Ca-357, Ca-923, Ca-930 and Ca-954. In addition, among the near-complete sequences, clones Ca2-912, Ca2-917 and Ca2-970 were identical and so were the clones Ca2-341, Ca2-357, Ca2-923 and Ca2954. All these near complete sequences formed a highly supported clade (89 and 99\% for MP and NJ bootstraps) (95-97\% sequence similarities) with the Beggiatoa spp. retrieved from marine sediments of dead zones in northern Europe, clones Limfjorden (Danish inlet) L8, D4, L22 and L6. Additionally, one distinct clone from the 2007 sample (Ca2-329) did not have a parallel in the previous partial $16 \mathrm{~S}$ library, but formed a well supported cluster with the Beggiatoa clones Limfjorden L9 and Dangast (German inlet) A9 (100\% for MP and NJ bootstraps) (94\% sequence similarities).

Microscopic Analysis of the Microbial Mat.

The microbial mat biomasses used for molecular analyses were mostly dominated by filamentous cells with diameter ranging from 18 to $28 \mu \mathrm{m}$, with elemental-sulphur granules arranged in a banding pattern (Fig. 4) and gliding behaviour with frequent rotation along their axes. Detailed video records of these gliding-rotating filaments showed that sulphur granules flanking the patterned-bands were always located at the periphery of filaments (Fig. 4c), consistent with the presence of a large central vacuole inside each tandem-arranged cell. $\mathbf{a}$

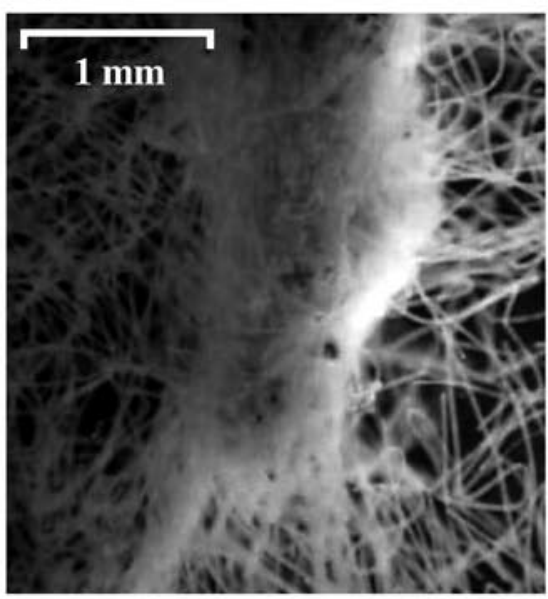

b

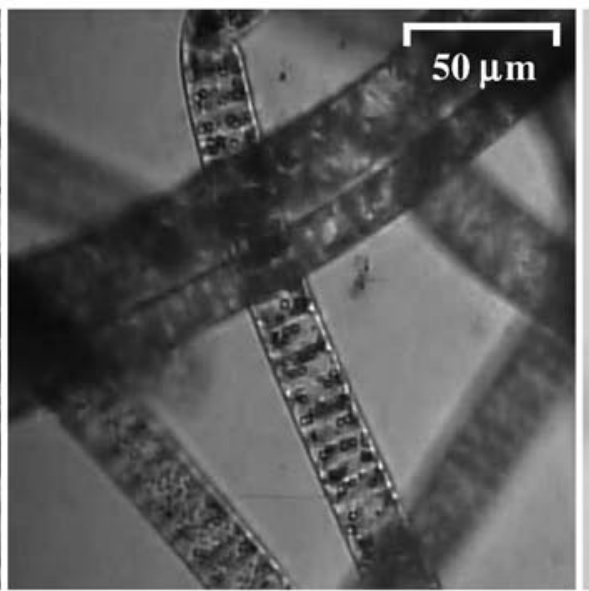

c

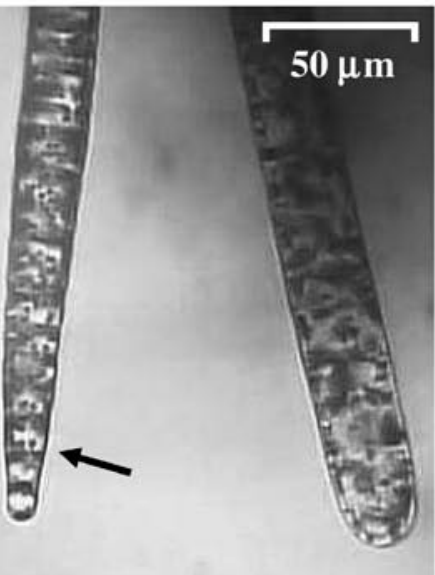

FIGURE 4. Mat forming cells collected from the water-sediment interface under the study site (2006 sample). a) Dark field micrography with perpendicular fluorescent illumination of self-aggregating cells used for molecular analysis. b) Phase contrast micrography showing most abundant trichomes with band-arranged distribution of sulphur globules. c) Bright field micrography with two different ending morphologies of trichomes. Arrow indicates sulphur globules inside filaments.

Figura 4. Células formadoras de tapete colectadas desde la interfase agua-sedimento en el sitio de estudio (muestra del 2006). a) Microfotografía a campo oscuro, iluminado con luz fluorescente perpendicular, de biomasa de células autoagregantes usada para el análisis molecular. b) Microfotografía de contraste de fase que muestra detalle de tricomas más abundantes con gránulos de azufre distribuidos en bandas. c) Microfotografía de campo brillante con dos diferentes morfologías de extremos de tricomas. La flecha señala gránulos de azufre dentro de los filamentos. 


\section{DISCUSSION}

Phylogenetic Sulphide-Oxidizing Cells Affiliation. This is the first study showing microscopic morphology reporting affiliation of filamentous organisms that compose the sulfide-oxidizing mat over marine sediments enriched by intensive aquaculture in the southern Chilean inlets. The observed morphology of Beggiatoa cells seems to be synapomorphic between the bifurcated phylogenetic clade (Fig. 3) formed by the Beggiatoa spp. of this study and their closest vacuolated, nitrate-storing and DNRA-driving relatives (Clones Limfjorden L8, D4, L22, L6 and L9 and clone Dangast A9) (Mussmann et al. 2003). This findig allow us to postulate that Beggiatoa mat studied was dominated by a vacuolated population potentially capable of coupling DNRA with sulphide-oxidation. Further examinations of nutrient fluxes in this anthropogenic environment would be then required to evaluate some possible biogeochemical implications of DNRA in the mat, including: (1) the increment of nitrate-dependent ammonium production (Christensen et al. 2000; Graco et al. 2001) and (2) the possible chemosymbiosis between Beggiatoa and anammox (Prolopenko et al. 2006).

\section{Methodological Considerations}

The procedure used here for collection and cleaning of gliding Beggiatoa cells is similar to other previous studies published elsewhere (Kojima \& Fukui 2003; Ahmad et al. 1999). However, our study is also the first to apply this method to preliminarily explore the genetic diversity of accompanying microbiota. Using this protocol, we can hypothesize several scenarios for explaining the presence of accompanying microbiota, such as more or less physical attachments with Beggiatoa filaments, a strong chemotactism attraction for them, or simply the fact that these organisms were driven by Beggiatoa motions. In any case, their presence can be a good indication for a narrow and probably syntrophic interaction. Moreover, hypotheses on the physiology of retrieved non-Beggiatoa clones presented in this study are considered preliminary, and further analyzes are required to demonstrate the level of activity of accompanying microbiota (by metabolic keygene expression measurements) and the specific niches utilized (by fluorescence in situ hybridization). Besides, the detailing level of interpretations of partial 16S rRNA sequences (fragments of only $\sim 500 \mathrm{pb}$ ) must be achieved with care. Considering these previous caveats, the following discussion is intended to understand the interpreted metabolic roles of Beggiatoa and accompanying bacterial microbiota in sediment beneath salmon farm.

Metabolic and Ecological Considerations for Identified ACCOMPANYING BACTERIA

Sulphate-reducing Deltaproteobacteria (SRB) are often the major drivers of marine organic matter decomposition under anoxic conditions and are responsible for sulphidogenic activity in sea bed sediments enriched with high organiccarbon input (Jørgensen \& Nelson 2004). The presence of these SRB in the top layer of sediments beneath the salmon farms, and its possible co-habitation with the sulphideoxidizing bacteria (SOB), e.g. Beggiatoa mat, underneath cages of salmon farm is intriguing because they may drive an intense sulphur cycle. Our findings suggested that Beggiatoa cells might have a very close interaction with SRB because these were intrinsically enriched in the upper sediment layers covered by the Beggiatoa mat. This kind of intense sulphur cycle has previously been described for areas beneath intensive shellfish aquaculture, with other SRB and different SOB (Asami et al. 2005). We hypothesize a mutualistic relationship between Beggiatoa and SRB, since some SRB populations could become less inhibited by sulphide (Reis et al. 1991) in this microenvironment where biological scavengers for $\Sigma \mathrm{H}_{2} \mathrm{~S}\left(\mathrm{H}_{2} \mathrm{~S}, \mathrm{HS}^{-}\right.$and $\left.\mathrm{S}^{2-}\right)$ are active (Sayama et al. 2005). On the other hand, it has been found that some SRB are inhibited by some nitratereducing and sulphide-oxidizing bacteria (NR-SOB), like Thiomicrospira sp., in the presence of nitrate, where nitrite released by these bacteria was demonstrated to downregulate operons involved in dissimilatory sulphate-reduction by the SRB Desulfobibrio vulgaris (Haveman et al. 2005). Beggiatoa spp. in our samples are potentially capable of coupling DNRA with sulphide-oxidation (considered also as NR-SOB), process in which nitrate is directly reduced to ammonium, and until our knowledge with no reports for possible release of any residual intermediary nitrite. By doing it, the Beggiatoa mat biomass could then act as a potent competitive inhibitors for other NR-SOB (Asami et al. 2005; Christensen et al. 2000), like Thiomicrospira sp. Therefore, we could speculate that some SRB can be closely related to Beggiatoa mat because these SRB would be beneficed by the sulphide scavenger effect of Beggiatoa and the displacement of any possible bacterial SRB inhibitors (like Thiomicrospira sp). The sulphur-cycle involved in turn might affect the overall carbon mineralization rate (by a raised activity of SRBs) inside these organic matterenriched environments with anthropogenic influence and thus require further evaluation.

Furthermore, it is interesting to note the presence of two clones (Ca1-E02 and Ca1-F03) closely affiliated with the uncultured Desulfocapsa sp. (94-97\% sequence similarity). Members of this genus are, like D. thiozymogenes (87-89\% sequence similarity) (Janssen et al. 1996) and D. sulfoexigens (88-90\% sequence similarity) (Finster et al. 1998), strictly anaerobic sulphate reducers with the frequent ability to drive chemolitotrophic disproportionation of elemental sulphur or thiosulphate to sulphate and sulphide. These processes, known as sulphur dismutations or fermentations, 
have been recognized in numerous sulphate reducers but are mostly incapable of sustaining growth (Thamdrup et al. 1993; Jørgensen \& Bak 1991). However, D. thiozymogenes and $D$. sulfoexigens are able to couple thiosulphate and sulphur disproportionation with growth when inorganic sulphide scavengers, like colloidal ferric hydroxide, were amended during culture (Finster et al. 1998; Janssen et al. 1996). Therefore, we could speculate the occurrence of these metabolisms in a microenvironment where biological scavengers for $\mathrm{\Sigma}_{2} \mathrm{~S}$ (Beggiatoa) are already operating.

The Sulfurovum OTUs suggests the presence of a possible pathway for elemental sulphur oxidation. The nearest sequences to these groups include some frequently retrieved 16S rRNA genes from methane seep or hydrothermal sediments (Lloyd et al. 2006, Teske et al. 2002) and symbiotic bacteria of organisms living in these environments (Nakagawa et al. 2005). One of the nearest cultured reference, Sulfurovum lithotrophicum (Inagaki et al. 2004) (89-94\% sequence similarity), is a specialized chemolithoautotrophic and non-motile bacterium able to use elemental sulphur or thiosulphate as sole electron donor and oxygen (optimum 5\% in gas phase) or nitrate as electron acceptor. Based on this reference, possible Sulfurovum-driving chemolitotrophic sulphur-oxidation in this environment would indicate a necessity for available oxidizing agents, but this would require further detailed examination.

On the other hand, Sulfurospirillum OTU is indicative of the presence of metabolically versatile bacteria. Different species of this genus can drive elemental sulphur oxidizing or reducing reactions with a broad spectrum of oxidant and reductive powers (Jensen \& Finster 2005). Detection of Sulfurospirillum sequences has also been reported in Beggiatoa mat communities from cold seep sediments (McHatton et al. 1996), suggesting that the coexistence of Sulfurospirillum sp. and Beggiatoa sp. may be a common phenomenon. In addition, the close cultured relative for the Fusibacter OTU, Fusibacter paucivorans (Ravot et al. 1999), is a strictly anaerobic, motile, Gram-positive, heterotrophic bacterium capable of fermenting organic compounds, as well as oxidizing organic compounds using thiosulphate and sulphur but not sulphate as an electron acceptor to produce sulphide. As suggested for Deltaproteobacteria-related clones, an elemental sulphur-enriched microenvironment with active biological sulphide scavengers seems to be a favourable habitat for elemental sulphur respiration of Sulfurospirillum or Fusibacter like-bacteria.

\section{Concluding Remarks}

In summary, we have presented the first phylogenetic analyses for Beggiatoa mats beneath intensive salmon farms in Chile. The finding of Beggiatoa mats directly beneath these fish cages but not outside clearly indicated significant benthic organic enrichment due to aquaculture activities. Furthermore, the coexistence of the different sulphurcycling functional groups, associated with the Beggiatoa mat strongly suggests intense sulphur -cycling within these aquaculture-impacted sediments involving sulphatereducing bacteria and sulphide-oxidizing Beggiatoa, and the subsequently produced elemental sulphur could become available for multiple bacterial intermediaries. Further investigations on the actual occurrences and rates of these processes are much needed to understand how the benthic biogeochemical parameters and the underlying microbial processes are responding to the worldwide increase of aquaculture activities.

\section{ACKNOWLEDGEMENTS}

We are grateful to Adrián Villarroel and Luis Henríquez, the scuba divers that collected samples. This work was supported by the Andes Foundation, Chile, the French ANR-IFB Deep Oases and the German DAAD program (A0703361). We also thank Marcel Kuypers, Rudi Amann and the Molecular Ecology laboratory at the MPI-MM in Bremen, Germany, for the access to molecular ecology facilities.

\section{BIBLIOGRAPHY}

Ahmad, A, J. P. Barry J.P. \& D. C. Nelson. 1999. Phylogenetic affinity of a wide, vacuolate, nitrate-accumulating Beggiatoa sp. from Monterey Canyon, California, with Thioploca spp. Applied and Environmental Microbiolgy 65: 270-277.

Asami, H., MAida \& K. Watanabe. 2005. Accelerated Sulfur Cycle in Coastal Marine Sediment beneath Areas of Intensive Shellfish Aquaculture. Applied and Environmental Microbiology 71: 2925-2933.

Benson, D. A., I. Karsch-Mizrachi, D. J. Lipman, J. Ostell, B. A. Rapp \& L. Wheeler. 2000. GenBank. Nucleic Acid Research 28: 15-18.

Bissett, A., J. Bowman \& C. Burke. 2006. Bacterial diversity in organically-enriched fish farm sediments. FEMS Microbiology Ecology 5: 48-56.

Brooks, K. M., A. R. Stierns, C. V. W. Mahnken, D. B. Blackburn. 2003. Chemical and biological remediation of the benthos near Atlantic salmon farms. Aquaculture 219: 355-377.

Buschmann, A. H., M. C. Hernandez-Gonzalez, C. Aranda, T. Chopin, A. Neori, C. Halling, M. Troell. 2008. Mariculture Waste Management. In: S.E. Jørgensen, B.D. Fath (Eds), Ecological Engineering, Elsevier, Oxford, Vol. 3 of Encyclopedia of Ecology. pp. 2211-2217.

Christensen, P. B., S. Rysgaard, N. P. Sloth, T. Delsgaard \& S. SChwÄrtER. 2000. Sediment mineralization, nutrient fluxes, denitrification and dissimilatory nitrate reduction, to ammonium in an estuarine fjord with sea cage trout farms. Aquatic Microbial Ecology 21: 73-84.

Cole, J. R., B. Chai, T. L. Marsh, R. J. Farris, Q. Wang, S. A. 
Kulam, S. Chandra, D. M. McGarrell, T. M. Schmidt, G. M. Garrity \& J. M. TiedJe. 2003. The Ribosomal Database Project (RDP-II): previewing a new autoaligner that allows regular updates and the new prokaryotic taxonomy. Nucleic Acids Research 31: 442-443.

Finster, K., W. Liesack \& B. Thamdrup. 1998. Elemental sulfur and thiosulfate disproportionation by Desulfocapsa sulfoexigens sp. nov., a new anaerobic bacterium isolated from marine surface sediment. Applied and Environmental Microbiology 64: 119-125.

Graco, M., L. Farías, V. Molina, D. Gutiérrez \& L. P. Nelsen. 2001. Massive developments of microbial mats following phytoplankton blooms in a naturally eutrophic bay: Implications for nitrogen cycling. Limnology and Oceanography 46: 821-832.

Haveman, S.A., E. A. Greene \& G. Voordouw. 2005. Gene expression analysis of the mechanism of inhibition of Desulfovibrio vulgaris Hildenborough by nitrate-reducing, sulfide-oxidizing bacteria. Environmental Microbiology 7: 1461-1465.

Huber, T., G. Faulkner \& P. Hugenholtz. 2004. Bellerophon; a program to detect chimeric sequences in multiple sequence alignments. Bioinformatics 20: 2317-2319.

Inagaki, F., K. Takai, K. H. Nealson \& K. Horikoshi. 2004. Sulfurovum lithotrophicum gen. nov., sp. nov., a novel sulfur-oxidizing chemolithoautotroph within the epsilonProteobacteria isolated from Okinawa Troughhydrothermal sediments. International Journal of Systematic and Evolutionary Microbiology 54: 1477-1482.

Janssen, P.H., A. Schummann, F. BaK \& W. Liesack. 1996. Disproportionation of inorganic sulfur compounds by the sulfate-reducing bacterium Desulfocapsa thiozymogenes gen. nov., sp. nov. Archives of Microbiology 166: 184192.

Jensen, A. \& K. Finster. 2005. Isolation and characterization of Sulfurospirillum carboxydovorans sp. nov., a new microaerophilic carbon monoxide oxidizing epsilon Proteobacterium. Antonie Van Leeuwenhoek. 87: 339-353.

Jørgensen, B. B. \& F. BAK. 1991. Pathways and microbiology of thiosulfate transformations, and sulfate reduction in a marine sediment (Kattegat, Denmark). Applied and Environmental Microbiolgy 57: 847-856.

Jørgensen, B. B. \& D. Nelson. 2004. Sulfide oxidation in marine sediments: Geochemistry meets microbiology. Geological Society of America. Special Paper 379.

Jørgensen, B. B., A. Teske \& A. Ahmad. 2005. In: G.M. Garrity, D.J. Brenner, N.R. Krieg, J.T. Staley (Eds.) Bergey's Manual of Systematic Bacteriology, 2nd ed., Vol. 2 (The Proteobacteria), Springer, New York, pp. 171-178.

Kalanetra, K.M., S. L. Huston, S.L. \& D. C. Nelson. 2004. Novel, attached, sulfur-oxidizing bacteria at shallow hydrothermal vents possess vacuoles not involved in respiratory nitrate accumulation. Applied and Environmental Microbiolgy 70, 7487-7496.

KoлIma, H. \& M. Fukui. 2003. Phylogenetic analysis of Beggiatoa spp. from organic rich sediment of Tokyo Bay, Japan. Water Research 37: 3216-3223.

Lavik, G., T. Stührmann, V. Brüchert, A. Van der Plas, V. Mohrholz, P. Lam, M. Mussmann, B. Fuchs, R. Amann, U. LASS \& M. KUYPERS. 2009. Detoxification of sulphidic
African shelf waters by blooming chemolithotrophs. Nature 457: 581-584.

Lloyd K. G., D. B. Albert, J. F. Biddle, J. P. Chanton, O. Pizarro \& A. Teske. 2010. Spatial structure and activity of sedimentary microbial communities under a Beggiatoa spp. mat in a Gulf of Mexico hydrocarbon seep. PLoS ONE 5: e8738. doi:10.1371/journal.pone.0008738.

Lloyd, K. G., L. Lapham \& A. Teske. 2006. An anaerobic methaneoxidizing community of ANME-1b archaea in hypersaline Gulf of Mexico sediments. Applied and Environmental Microbiolgy 72: 7218-7230.

Marchant, R., I. M. Banat, T. J. Rahman \& M. Berzano. 2002. The frequency and characteristics of highly thermophilic bacteria in cool soil environments. Environmental Microbiology 4: 595-602.

Mchatton, S. C., J .P. Barry, H. W. Jannasch \& D. C. Nelson. 1996. High nitrate concentrations in vacuolate, autotrophic marine Beggiatoa spp. Applied and Environmental Microbiolgy 62: 954-958.

Mills, H. J., R. J. Martínez, S. Story \& P. A. Sobecky. 2004. Identification of members of the metabolically active microbial populations associated with Beggiatoa species mat communities from Gulf of Mexico cold-seep sediments. Applied and Environmental Microbiolgy 70: 5447-5458.

Mussmann, M., H. N. Schulz, B. Strotmann, T. Kuaer, L. P. Nielsen, R. A. Rosselló-Mora, R. I. Amann \& B. B. Jørgensen. 2003. Phylogeny and distribution of nitratestoring Beggiatoa spp. in coastal marine sediments. Environmental Microbiology 5: 523-533.

Muyzer, G., A. Teske, C. O. Wirsen, \& H. W. Jannasch. 1995. Phylogenetic relationships of Thiomicrospira species and their identification in deep-sea hydrothermal vent samples by denaturing gradient gel electrophoresis of $16 \mathrm{~S}$ rDNA fragments. Archives of Microbiology 164: 165-172.

Nakagawa, S., K. Takai, F. Inagaki, H. Hirayama, T. Nunoura, K. Horikoshi \& Y. SAKo. 2005. Distribution, phylogenetic diversity and physiological characteristics of epsilonProteobacteria in a deep-sea hydrothermal field. Environmental Microbiology 7: 1619-1632.

Nelson, D. C., C. O. Wirsen, H. W. Jannasch. 1989. Characterization of large, autotrophic Beggiatoa spp. abundant at hydrothermal vents of the Guaymas Basin. Applied and Environmental Microbiology 55: 2909-2917.

Prokopenko, M. G., D. E. Hammond, W. M. Berelson, J. M. Bernhard, L. Stott \& R. Douglas. 2006. Nitrogen cycling in the sediments of Santa Barbara basin and Eastern Subtropical North Pacific: Nitrogen isotopes, diagenesis and possible chemosymbiosis between two lithotrophs (Thioploca and anammox) - "riding on a glider", Earth and Planetary Science Letters 242: 186-204.

Ravot, G., M. Magot, M. L. Fardeau, B. K. Patel, P. Thomas, J. L. García \& B. Ollivier. 1999. Fusibacter paucivorans gen. nov., sp. nov., an anaerobic, thiosulfate-reducing bacterium from an oil-producing well. International Journal of Systematic Bacteriology 49: 1141-1147.

Reis, M.A.M., P. C. Lemos, J. S. Almeida \& M. J. T. Carrondo. 1991. Evidence for the intrinsic toxicity of H2S to sulphate-reducing bacteria. Environmental Biotechnology $36,145-147$. 
Sayama, M., N. Risgaard-Petersen, L. P. Nielsen, H. Fossing \& P. B. Christensen. 2005. Impact of bacterial NO3(-) transport on sediment biogeochemistry. Applied and Environmental Microbiolgy 71: 7575-7577.

Schulz, H.N. \& B. B. Jørgensen. 2001. Big bacteria. Annual Review of Microbiology 55, 105-137.

Schulz, H. N., B. B. Jørgensen, H. A. Fossing, N. B. Ramsing. 1996. Community structure of filamentous, sheath-forming sulfur bacteria, Thioploca spp., off the coast of Chile. Applied and Environmental Microbiolgy 62: 1855-1862.

Tamura, K., J. Dudley, M. Nei \& S. Kumar. 2007. MEGA4: Molecular Evolutionary Genetics Analysis (MEGA) software version 4.0. Molecular Biology and Evolution 24, 1596-1599.
Teske, A., K. U. Hinrichs, V. Edgcomb, A. de Vera Gomez, D. Kysela, S. P. Sylva, M. L. Sogin \& H. W. Jannasch. 2002. Microbial diversity of hydrothermal sediments in the Guaymas Basin: evidence for anaerobic methanotrophic communities. Applied and Environmental Microbiology 68: 1994-2007.

Thamdrup, B., K. Finster, J. W. Hansen \& F. BaK. 1993. Bacterial disproportionation of elemental sulfur coupled to chemical reduction of iron or manganese. Applied and Environmental Microbiology 59: 101-108.

Wang, Q, G. M. Garrity, J. M. Tiedje \& J. R. Cole. 2007. Naïve Bayesian Classifier for Rapid Assignment of rRNA Sequences into the New Bacterial Taxonomy. Applied and Environmental Microbiology 73: 5261-5277.

Recibido: 23.04 .10

Aceptado: 22.07.10 